\title{
Guns in the world: old news and new news
}

\section{K K Christoffel}

\section{The worldwide small arms epidemic must be controlled}

l

$\mathrm{n}$ the wake of September 11, it is more obvious than ever that small arms can bring about large carnage, and that they will continue to figure prominently in regional conflicts. It is no exaggeration to say that it is now urgent to understand the public health crises linked to small arms, and to devise means to minimize these. This commentary offers some information and thoughts to inform the discourse in the health arena drawn from an international conference.

The first ever large international meeting on guns was held in New York, 9-20 July 2001. The meeting was the "United Nations Conference on the Illicit Trade in Small Arms And Light Weapons In All Its Aspects". I attended the meeting as a representative of the Handgun Epidemic Lowering Plan (HELP) Network (www. helpnetwork.org). HELP was one of a small contingent promoting public health as part of "all the aspects". Most of the hundreds of involved nongovernmental organizations (NGOs) approach small arms as an issue that is primarily related to war and crime. The goal of the health groups was to strengthen awareness of health perspectives on reducing the international toll of small arms. While a Canadian view on this has recently been published ${ }^{1}$ the current commentary summarizes what another North American health professional learned from the meeting.

\section{BACKGROUND ON THE CONFERENCE}

In 2000, the United Nations adopted a new Convention Against Transnational Organized Crime. In May 2001, the United Nations General Assembly added a "Firearm Protocol" to the Convention, intended to "promote, facilitate and strengthen cooperation among State parties in order to prevent, combat, and eradicate the illicit manufacturing and trafficking in firearms, their parts, components and ammunition". ${ }^{2}$ The July 2001 meeting was organized to address the issue of small arms "more comprehensively". The definition of "small arms" was the subject of much debate before and during the conference, but to most the meaning was obvious: deadly weapons that can be readily operated by one person (for example, firearms, grenades, and other devices excluding landmines).

It is estimated that 500000 people die worldwide each year due to injuries from small arms. ${ }^{3}$ Because fragile communities, economies, and governments around the world are being held hostage by those wielding guns, 170 countries with varied political agendas agreed to a meet to try to deal cooperatively with this issue. It was expected that the conference would, at best, generate a non-binding consensus statement.

\section{THE CONFERENCE ITSELF}

NGO representatives were permitted to view only a few of the formal conference events. Other work was done at consulates, in the United Nations's Vienna Café, and other venues. The NGO community held a parallel meeting. Components included presentations tailored to each day's theme (women, children, Africa, Asia ...), updates on the closed meetings, and strategy and brainstorming sessions. Forty one NGO speakers made presentations to the delegates. Most of the NGOs (all but a small group led by the US National Rifle Association) worked under the coordinating umbrella of the International Action Network on Small Arms (IANSA). Texts of most of the informative and moving NGO presentations are available at the IANSA web site, www.iansa.org.

As in some prior meetings on international agreements, the US was isolated. The US took the position that any agreement must be limited to weapons already regulated in the US, could not in any way address civilian possession of weapons, and must not discourage the international sale of weapons to "nonstate actors" (that is, rebel forces). This position was opposed by most of the NGOs, including US ones. In a statement that brought an ovation, the President of the Million Mom March-Mary Leigh Blek—rebutted, saying:

"The US official report to this body does not represent the thinking of the American public. ... I am here to set the record straight because many polls conducted in our country are very clear on this point. The majority of my fellow citizens favor better regulation of guns, including licensing of gun owners, registration of guns and closing the gun show loophole that allows criminals and minors to get weapons. ...". ${ }^{4}$

In the end, the agreement reached was modest. The plan of action is summarized on the United Nations Department for Disarmament Affairs web site:

"The eighty-six paragraph programme of action is a comprehensive document, containing unprecedented political commitments and concrete measures at the national, regional and global levels to tackle the illegal trade in small arms. It also contains provisions on enhancing cooperation among States and providing assistance to affected States, as well as follow-up mechanisms to oversee its implementation and further development". ${ }^{5}$

Though IANSA points out that a number of critical commitments were left out of the final plan, ${ }^{6}$ valuable lessons were learned at this conference. These can be categorized into "what was familiar" and "what was unfamiliar" in international small arms work as compared to domestic work.

\section{WHAT IS FAMILIAR ABOUT SMALL ARMS INJURY PREVENTION WORK INTERNATIONALLY Inadequate data}

In the US, we are well aware of the need for more, better, and coordinated data on gun deaths and injuries. The Just The Facts Campaign (www.jtfcampaign.org) has built support for federal funding for a national violent death reporting system, now being developed with philanthropic and federal funding. Internationally, the data void is much more severe. Most countries do not have reliable national death data collection systems, and many lack such systems even in their largest cities. When death data are available, they are often not coded in a way that permits identification of those due to any firearms, let alone specific types of firearms. The data available are often only those from the police, and thus limited to homicide and some unintentional injuries (excluding suicides). Data are most limited in the impoverished countries that suffer the highest rates of death from small arms.

The World Health Organization (WHO) is focusing attention on gathering and analyzing information on small arms. At the United Nations meeting WHO released a new report, Small Arms and Global Health, analyzing firearm injury patterns from 52 high and middle income nations with the best data on firearm related deaths (see table 1 ). ${ }^{3}$

There was consensus at the United Nations meeting that better data must become a top priority in small arms injury reduction. Since that meeting, 
Table 1 Firearm deaths in a one year period in 52 countries, mid-1990s

\begin{tabular}{lrrr}
\hline Manner of death & Males & Females & Both sexes \\
\hline Homicides & 72216 & 7104 & 79320 \\
Suicides & 25359 & 3180 & 28539 \\
Undetermined & 4466 & 538 & 5004 \\
Accidental & 2452 & 278 & 2730 \\
Total & 104493 & 11100 & 115593 \\
\hline
\end{tabular}

Countries which contributed data for one year in the early-to-mid 1990s (but not always the same year), were Albania, Australia, Austria, Belgium, Brazil, Bulgaria, Canada, Colombia, Croatia, the Czech Republic, Denmark, the Dominican Republic, Ecuador, Estonia, Finland, France, Germany, Greece, Hong Kong Special Administrative Region of China, Hungary, Iceland, Ireland, Israel, Italy, Japan, Kuwait, Latvia, Lithuania, Luxembourg, Macau, the Former Yugoslav Republic of Macedonia, Malta, Mauritius, Mexico, Mongolia, the Netherlands, New Zealand, Norway, the Philippines, Portugal, the Republic of Moldova, the Republic of Korea, Romania, Singapore, Slovakia, Slovenia, Spain, Sweden, Thailand, the United States, the United Kingdom, and Uruguay.

Source: WHO World Health Report database. ${ }^{3}$ nation status reports have been compiled for 62 nations (and three cities) using the WHO and other information to summarize violent and firearm deaths by age and sex. The reports, which are updated periodically, are available online from www.helpnetwork.org (for injury data), www.research.ryersion.ca/SAFER-Net/ (for related policy information).

In the US, several highly publicized shootings educated Americans on the value of unique identification numbers on guns. These often allow law enforcement officials to reconstruct how the gun got to the scene, which may reveal laws ferring weapons to prohibited users). crimes and to the development of initiatives to prevent both the crimes and the injuries. ${ }^{7}$ Internationally, there is less marking and tracing of firearms than in the US. Many countries do not require marking and those that do often do not require that the markings be unique. This means, for example, that there are (or were) crude shops in the Afghani hills, where guns are (or were) made and shipped to markets in the region, with no ability to identify where the guns come from or to trace their journeys to where they are eventually used.

\section{Importance of "marking and tracing"} that were broken (for example, in transThis, in turn, leads to the prosecution of
Some years ago, a similarly chaotic situation made it difficult to trace motor vehicles internationally. This was corrected by the international adoption of standards for generating and affixing unique vehicle identification numbers on every car manufactured and sold. Similar international standards for marking and tracing small arms should be possible.

\section{Other familiarities}

As in the US, most who die from small arms internationally are young men; the victims also include the many who are not wounded, but whose lives are harmed by the loss of those who are; the prevention focus is on illegally acquired weapons, though most weapons start their paths to destruction in legal sales. Problems are caused by inconsistent laws across jurisdictions. Prevention planning everywhere must balance legitimate needs for self protection versus unintended consequences due to the easy accessibility of small arms. The focus of the United Nations discussions on criminal justice issues mirrored discussions that occurred in the US until 5-10 years ago.

As in the US, the most visible work to reduce the toll related to small arms is done by groups that focus on information (such as the WHO, the Geneva
Table 2 A breakdown of the 60 known legal small arms exporting countries

\begin{tabular}{lcc}
\hline Level of exportation & Total annual sales & Contributing nations \\
\hline Major exporters ( $\$ 75$ million/year) & $\sim \$ 2$ Billion & 4 Countries* \\
Mid level exporters $(\$ 1-75$ million/year) & $\$ 497$ Million & 18 Countries $\dagger$ \\
Minor exporters $(<\$ 1$ million/year) & $<\$ 10$ Million & 20 Countries $\ddagger$ \\
Value unknown exporters & $? ? ?$ & 18 Countries \\
\hline
\end{tabular}

*United States (>\$1.2B), Germany (\$384M), Brazil (\$100-150M), Russia (\$100-150M). †Argentina, Austria, Belgium, Canada, China, Czech Republic, Finland, France, Italy, Pakistan, Poland, Romania, Spain, South Africa, South Korea, Sweden, Switzerland, United Kingdom. $\ddagger$ Australia, Chile, Colombia, Croatia, Denmark, Japan, India, Indonesia, Latvia, Malaysia Mexico, Netherlands, New Zealand, Norway, Philippines, Portugal, Slovakia, Swaziland Thailand, Turkey.

$\S$ Armenia, Belarus, Bosnia, Bulgaria, Cyprus, Ecuador, Egypt, Greece, Hungary, Iran, Israel, Kazakhstan, Jordan, North Korea, Singapore, Slovenia, Ukraine, Zimbabwe. Source: Adapted from Small Arms Survey 2001.10 based Small Arms Survey and the International Committee of the Red Cross), strategy (such as IANSA), and action in the international political arena (such as Human Rights Watch, Amnesty International, Saferworld, Oxfam, and International Physicians for the Prevention of Nuclear War). ${ }^{8}$

\section{WHAT WAS UNFAMILIAR ABOUT THE SMALL ARMS INJURY PREVENTION WORK INTERNATIONALLY}

The unfamiliar discussions were the most helpful in clarifying how US domestic gun injury prevention work fits into the international efforts, and what role health professionals might play.

\section{The US should be a leader in this work}

Because of the huge toll of guns in the US and all that needs to be done to reduce it, ${ }^{9}$ the US has developed practices that may be useful in the rest of the world. These include approaches to data collection and analysis and to weapon marking and tracing. As international work to reduce small arms deaths and injuries grows, the US should be encouraged to provide technical assistance in these aspects and others.

In contrast to the US leadership opportunity, the US is widely perceived as opposing effective action to reduce the toll of small arms. Its position at the United Nations meeting emphasized the Bush administration's view that civilian possession of small arms is sacrosanct in the US and cannot be addressed in international agreements. The US opposed international regulation of sales to nonstate parties (for example, Al Qaeda), which many nations see as essential to curbing the flow of weapons. The US also opposes the involvement of NGOs in policy implementation related to small arms, seeking to preserve this for governments. This contrasts with the role of "civil society" elsewhere. These positions alienate NGOs confronting small arms around the world. They respond with a mixture of puzzlement and indignation.

\section{Nations are arms producing $O R$ arms using}

To those involved in international small arms work, the world is divided into countries that sell small arms, and those that buy them. Among the arms producing nations, the US is the largest supplier, producing an estimated $50 \%$ of all small arms produced annually (table 2). ${ }^{10}$ Many NGOs see the arms producing nations as ignoring the effects of gun sales, prioritizing instead the economic benefits of gun production and sales to the countries where manufacturers are based. ${ }^{10}$

Further, many see the arms sales as a means that rich gun producing nations 
use to further weaken nations that are already weak, making them turn to the gun selling nations in a dependent way that advances the goals of rich nations. We need to understand if and how US policies related to gun exports may be destructive internationally and, if so, how they might be changed.

The international small arms problem has grown since the end of the Cold War

Many referred to the current small arms catastrophe as "the legacy of the Cold War". Because they are small, cheap, light weight, and easy to use, small arms draw virtually everyone into the pool of potential combatants in local conflicts; this includes children. Stockpiles of small arms from Eastern Europe, for example, have scattered across the globe to regions of conflict.

The trend towards civilian casualties in local conflicts is exacerbated by available small arms. Literature produced by the United Nations states that there has been a huge rise over the last century in the percentage of casualties during war: from $5 \%$ in the 1890 s to $15 \%$ during World War I, to 65\% during World War II, and $90 \%$ in the 1990s. ${ }^{11}$ Discussions identified small arms proliferation as a major contributor to this. When local conflicts break out, the area is flooded with small arms, sold to all sides by companies in producing nations. In these local conflicts, there is little distinction between the military and the populace, and the result is that most households-and, in particular, most young men-become armed. The arms they carry are then used not only in "battles of war", but also in daily situations that become deadly. As a result, even during war, many civilians are wounded in disputes that are unrelated-or only vaguely related-to the war. ${ }^{11}$

This story took some getting used to, but once I understood it, it made sense because of what I have learned from living in a US city. Here, when the combatant forces are gangs, the lines between those who are "in" and those who are "out" can be vague. When the gangs are armed, others arm themselves as well, using commercial streams that are built into manufacturer and retailer sales calculations. $^{1213}$ The weapons gangs carry find their way into all sorts of disputes (for example, domestic violence), and result in "non-combatant" deaths. ." We know it happens here and it is easy to believe that it happens elsewhere.

The indirect effects of available guns depend on where they are available The toll of guns in the US is not really a microcosm of what others in the world suffer, because we are a rich nation with stable infrastructures. As a result, rampant gun deaths are seriously disruptive to society only in local areas. Even in the worst hit areas, food still arrive in stores, banks remain open, phones work, the mail arrives, etc.

The effects of small arms proliferation in the rest of the world are much more severe. In countries with poor road systems, fragile social structures, and weak economies, all aspects of society are brought down by small arms run amok. The indirect consequences of gun violence include those familiar to us as well as impeded economic development, interrupted preventive and curative health care, malnutrition due to interruptions of food supply, and infections due to damaged water supplies.

\section{Interventions work differently in different settings}

Interventions that cannot work well in the US may work better in countries with weak infrastructures. For example, in the presence of Fed Ex, excellent highways, and easy car rentals, the effect of gun buy-backs will always be limited, because bought-back guns can be more or less instantly replaced. This will not be as true in places with impassable roads and great poverty. There, the collection of a few hundred weapons might well change the local situation dramatically for some period of time. (For more information on international efforts towards gun buy-backs and destruction, see www.miis.edu/rcenters-cns.html and the United Nations, Destruction Handbook. ${ }^{14}$ ) Thus Americans must be cautious in generalizing effects to other settings and should examine interventions that work in other settings to see if they can work in the US.

\section{Distinguishing conflict and post-conflict situations: the next step for public health?}

A concept from the international work promises to be useful in public health approaches to gun injury prevention. The "recipe" for post-conflict situations is referred to as Disarmament, Demobilization, and Reintegration. These steps are needed to help a community and its residents change from a war footing to peace time.

It is easy to apply this approach specifically to gun injury prevention. Widespread weaponry is acquired in response to a perceived threat, which is usually related to conflict of one type or another (rising crime, gang turf battle, domestic danger, etc). To reduce the damage done by the weapons in the short and long term, two steps are needed: prevention of acquisition and disarmament. Many of the efforts of the US "gun control" movement are aimed at the first. ${ }^{15-17}$

The "disarmament" step, which has not received as much attention, may hold a key to public health interventions to reduce the unintended consequences of small arms. Of course, the case will need to be made convincingly that the danger will not return and that there are paths to the future that do not require a gun on every hip or shoulder. When that case can be made, much will be possible.

\section{POSTSCRIPT}

A follow up to the United Nations conference will be held in a few years. Since the US produces more than $50 \%$ of the small arms in the world, yet suffers fewer than $10 \%$ of the deaths they cause, public health professionals in the US can no longer work in international isolation. US physicians must become increasingly involved to sustain the recent declines in the US, and to promote similar declines internationally. The first international meeting on small arms as a public health problem was held in Helsinki Finland in September 2001 and produced a "medical call to arms". ${ }^{18}$

\section{ACKNOWLEDGEMENTS}

Thanks to Philip Alpers, Harvard Injury Control Research Center; Matt Longjohn MD, and Jennifer Hurtarte at the HELP Network and Lavonne Payne (at the Children's Memorial Institute for Education and Research) for assistance in preparing this commentary.

Injury Prevention 2002;8:177-180

\section{Author's affiliation}

Pediatrics and Preventive Medicine, Feinberg Medical School at Northwestern University and Children's Memorial Institute for Education and Research

Correspondence to: Professor Katherine Kaufer Christoffel, 2300 Children's Plaza \#208,

Chicago, IL 60614, USA

kkauferchristoffel@northwestern.edu

\section{REFERENCES}

1 Cukier W, Chapdelaine A. Small arms: a major public health hazard. Medicine \& Global Survival 2001;7:26-32.

2 United Nations General Assembly. Protocol against the illicit manufacturing of and trafficking in firearms, their parts and components and ammunition, supplementing the UN convention against transnational organized crime. United Nations General Assembly Resolution 55/255, 31 May 2001

3 Villaveces A, Krug E, Butcchart A, et al. Small arms and global health. Geneva: Department of Injuries and Violence Prevention, Non-communicable Diseases and Mental Health, World Health Organization, 2001 (unpublished document WHO/NMH/VIP/01.1). Available from Department of Injuries and Violence Prevention, World Health Organization, 121 Geneva 27, Switzerland or at: http://www.who.int/ violence_injury_prevention/pdf/ small-arms-and-global-health.pdf. Accessed 11 March 2002

4 Million Mom March, USA Delivered by Mary Leigh Blek. Available at: www.un.org/Depts/ dda/CAB/smallarms/statements/Ngo/ mom.html. Accessed 11 March 2002.

5 Small arms conference concludes with consensus adoption of action programme. Available at: http://www.un.org/News/ Press/docs/2001/DC2795.doc.htm. Accessed 11 March 2002. 
6 UN Conference on the Illicit Trade in Small Arms and Light Weapons In All Its Aspects. New York, NY, USA, 9-20 July 2001. Available at: http://www.iansa.org/ calendar/2001UN/index.htm. Accessed 11 March 2002

7 Kuo A. Lawmakers OK new gun control plans. Associated Press, 23 June 2000.

8 Christoffel KK. Public health advocacy: process and product. Am J Public Health 2000:90:722-6

9 American Academy of Pediatrics, Committee on Injury and Poison Prevention. Firearm-related injuries affecting the pediatric population. Pediatrics 2000;105:888-95.

10 Graduate Institute of International Studies, Geneva. Small arms survey 2001: profiling the problem. Avon, UK: Oxford University Press, 2001

11 International Committee of the Red Cross. Arms availability and the situation of civilians in armed conflict. Geneva: International Committee of the Red Cross, 1999.

12 Legal citation: Hamilton v Accu-Tek, 935 F Supp 1307 (EDNY 1996).

13 Diaz T. Making a killing: the business of guns in America. New York, NY: The New Press; 1999

14 A destruction handbook: small arms, light weapons, ammunition and explosives. Available at: www.un.org/Depts/dda/ DDAPublications/desthbk.pdf. Accessed 11 March 2002.
15 The Brady Law: preventing crime and saving lives. Available at: www.bradycampaign.org/facts/gunlaws/ brady.asp. Accessed 11 March 2002.

16 The gun show loophole. Available at: www.gunfree.org/content/coalition/ coal_gunshow.html. Accessed 11 March 2002.

17 Licensing and registration: questions and answers. Available at: www.bradycampaign.org/facts/gunlaws/ licensing.asp. Accessed 11 March 2002.

18 A medical call to action to reduce small arms deaths and injuries. Available at: www.ippnw.org/HelsinkiMedCall.html. Accessed 11 March 2002.

\section{LACUNAE}

\section{Killer biscuits wanted for attempted murder (the actual Associated Press headline)}

inda Burnett, 23, a resident of San Diego, was visiting her in-laws and while there went to a nearby

supermarket to pick up some groceries. Several people noticed her sitting in her car with the windows

-rolled up and with her eyes closed, with both hands behind the back of her head. One customer who had been at the store for a while became concerned and walked over to the car. He noticed that Linda's eyes were now open, and she looked very strange. He asked her if she was okay, and Linda replied that she'd been shot in the back of the head, and had been holding her brains in for over an hour. The man called the paramedics, who broke into the car because the doors were locked and Linda refused to remove her hands from her head. When they finally got in, they found that Linda had a wad of bread dough on the back of her head. A Pillsbury biscuit canister had exploded from the heat, making a loud noise that sounded like a gunshot, and the wad of dough hit her in the back of her head. When she reached back to find out what it was, she felt the dough and thought it was her brains. She initially passed out, but quickly recovered and tried to hold her brains in for over an hour until someone noticed and came to her aid. And, yes, Linda is a blonde (contributed by Susan Baker).

\section{Chiropractic opinions on baby walkers}

The Chiropractic Association of Australia has added its voice to concerns over the use of baby walkers. The association argues that the products should be banned because, according to spokesman Benjamin Schutte, "in addition to the injury risk they are responsible for serious locomotor problems and faulty walking patterns". There are also concerns associated with prematurely encouraging walking. The issue was a focus of promotion during National Chiropractic Week May 20-27 (The Australian, April 2002).

\section{Apparent failure of shark repellent device}

A number of products have been developed to protect those in the water from attacks by sharks. In what is reported to be the first such attack an Australian scallop diver has been attacked and killed by a shark while wearing such a device. The professional diver was wearing a electronic deterrent product called a Shark POD when he was attacked and killed, probably by a $7 \mathrm{~m}$ long white pointer. Newspaper reports quote the company as saying that there had been no known attack of anyone wearing the device and a fellow diver as saying that divers thought the device would protect them against a cruising shark but not an aggressively hunting white pointer. These sharks are protected by Australian law (The Australian, May 2002). 